\title{
Autism spectrum disorders - an emerging area in psychopharmacology
}

\author{
Thomas Steckler • Will Spooren • Declan Murphy
}

Published online: 31 January 2014

(C) Springer-Verlag Berlin Heidelberg 2014

Autism spectrum disorder (ASD) is a high-cost, lifelong, neurodevelopmental condition currently affecting up to 1 child in every 88 (CDC 2012) and about $1 \%$ of adults (Brugha et al. 2011)_but the prevalence may be growing fast. It is characterized by a number of so-called core symptoms that reflect impairments in three main domains-social interaction, verbal and nonverbal communication, and unusual repetitive behaviors. In addition, many people with ASD suffer from additional mental health symptoms (most commonly depression, anxiety, OCD, and ADHD); cognitive deficits (including intellectual disability); and epilepsy and sleep problems; some (and especially lower functioning individuals) also show significant self-injurious behavior (Devine et al. 2013). This combination of "core" and "associated" symptoms comes at a very high cost to the affected individual and their families (Cadman et al. 2012).

While many different drugs are prescribed for the associated symptoms of ASD, there are no approved drugs specifically to treat core symptoms (Hsia et al. 2013; Murray et al. 2013; Politte and McDougle 2013). However, the field has recently made major progress in understanding the underlying neurobiology of ASD, which hopefully will lead us to novel therapeutic approaches, summarized in the reviews by Kleijer et al. (2014) and Vorstman et al. (2013). This, together with emerging technologies such as the generation of patientderived inducible pluripotent stem cells, enabled the

T. Steckler $(\bowtie)$

Janssen Research \& Development, Turnhoutseweg 30, 2340 Beerse, Belgium

e-mail: TSTECKLE@its.jnj.com

W. Spooren

F. Hoffmann-La Roche, Basel, Switzerland

D. Murphy

Sackler Institute for Translational Neurodevelopment at the Institute of Psychiatry, King's College, London, UK development of novel in vitro approaches that can be used for phenotypic screens (Cocks et al. 2014; Aigner et al. 2014; Dage et al. 2014), as well as the generation of novel preclinical in vivo models that facilitate our understanding of the neuronal networks involved and their role in symptomatology. In turn, these in vitro and in vivo assets could eventually be used to facilitate drug development in this field to demonstrate pharmacodynamic effects of novel treatments (Kas et al. 2013, 2014; Khatri et al. 2013; Petrinovic and Künnecke 2013) and help the development of novel biomarkers for ASD (Ruggeri et al. 2013). These advances should help inform a range of initiatives such as a concept paper currently being prepared by the European Medicines Agency on the development of medicinal products for treating ASD (European Medicines Agency 2013).

Not surprisingly, ASD research progress in some areas has been more substantial than in others. Nonetheless, recent advances in Fragile X syndrome suggest that this strategy is indeed viable (Pop et al. 2013; Jacquemont et al. 2013; Pop et al. 2014).

Despite these exciting developments, there are still major challenges and unresolved questions ahead. It is for this reason that international consortia have been formed, such as the European autism interventions - a multicentre study for developing new medications (EU-AIMS), a public private partnership within the context of the Innovative Medicines Initiative. The goals of EU-AIMS are to (1) develop and validate translational approaches for the advancement of novel therapies to treat ASD, (2) set new standards in research and clinical development to aid the drug discovery process, (3) identify and develop expert clinical sites across Europe to run clinical studies, and (4) create an interactive platform for ASD professionals and patients (Murphy and Spooren 2012). In fact, many of the authors contributing to this special issue are also members of the EU-AIMS consortium. These types of initiatives provide an opportunity to make a significant impact in ASD, which still remains an area of high unmet medical need. 
A better understanding of the pathogenesis of ASD, utilization of novel research tools, and better stratification of individuals entering clinical trials will hopefully facilitate the identification of novel pharmacological therapies for these debilitating disorders.

\section{References}

Aigner S, Heckel T, Zhang JD, Andreae LC, Jagasia R (2013) Human pluripotent stem cell models of autism spectrum disorder: emerging frontiers, opportunities, and challenges towards neuronal networks in a dish. Psychopharmacology. doi: 10.1007/s00213-013-3332-1

Brugha TS, McManus S, Bankart J, Scott F, Purdon S, Smith J, Bebbington P, Jenkins R, Meltzer H (2011) Epidemiology of autism spectrum disorders in adults in the community in England. Arch Gen Psychiatry 68:459-465

Cadman T, Eklund H, Howley D, Hayward H, Clarke H, Findon J, Xenitidis K, Murphy D, Asherson P, Glaser K (2012) Caregiver burden as people with autism spectrum disorder and attention-deficit/ hyperactivity disorder transition into adolescence and adulthood in the United Kingdom. J Am Acad Child Adolesc Psychiatry 51:879-888

CDC (2012) Prevalence of autism spectrum disorders - autism and developmental disabilities monitoring network, 14 sites, United States, 2008. MMWR 61:1-19

Cocks G, Curran S, Gami P, Uwanogho D, Jeffries AR, Kathuria A, Lucchesi W, Wood V, Dixon R, Ogilvie C, Steckler T, Price J (2013) The utility of patient specific induced pluripotent stem cells for the modelling of Autistic Spectrum Disorders. Psychopharmacology. doi: 10.1007/s00213-013-3196-4

Dage JL, Colvin EM, Fouillet A, Langron E, Roell WC, Li J, Mathur SX, Mogg AJ, Schmitt MG, Felder CC, Merchant KM, Isaac J, Broad LM, Sher E, Ursu D (2014) Pharmacological characterisation of ligand- and voltage-gated ion channels expressed in human iPSCderived forebrain neurons. Psychopharmacology. doi: 10.1007/ s00213-013-3384-2

Devine DP (2013) Self-injurious behaviour in autistic children: a neurodevelopmental theory of social and environmental isolation. Psychopharmacology. doi: 10.1007/s00213-013-3279-2

European Medicines Agency (2013) Concept paper on the development of medicinal products for the treatment of Autism Spectrum Disorder. EMA/CHMP/40896/2013

Hsia Y, Wong AYS, Murphy DGM, Simonoff E, Buitelaar JK, Wong ICK (2013) Psychopharmacological prescriptions for people with autism spectrum disorder (ASD): a multinational study. Psychopharmacology. doi: 10.1007/s00213-013-3263-x

Jacquemont S, Berry-Kravis E, Hagerman R, von Raison F, Gasparini F, Apostol G, Ufer M, Des Portes V, Gomez-Mancilla B (2013)
The challenges of clinical trials in fragile $\mathrm{X}$ syndrome. Psychopharmacology. doi: 10.1007/s00213-013-3289-0

Kas MJ, Glennon JC, Buitelaar J, Ey E, Biemans B, Crawley J, Ring RH, Lajonchere C, Esclassan F, Talpos J, Noldus LPJJ, Burbach JPH, Steckler T (2013) Assessing behavioural and cognitive domains of autism spectrum disorders in rodents: current status and future perspectives. Psychopharmacology. doi: 10.1007/s00213-0133268-5

Kas MJ, Modi ME, Saxe MD, Smith DG (2014) New technologies reveal the brain circuits of social behavior in rodents and advance the discovery of medications for autism spectrum disorder. Psychopharmacology. doi: 10.1007/s00213-014-3464-y

Khatri N, Simpson KL, Lin RCS, Paul IA (2013) Lasting neurobehavioral abnormalities in rats after neonatal activation of serotonin $1 \mathrm{~A}$ and $1 \mathrm{~B}$ receptors: possible mechanisms for serotonin dysfunction in autistic spectrum disorders. Psychopharmacology. doi: 10.1007/ s00213-013-3242-2

Kleijer KTE, Schmeisser MJ, Krueger DD, Boeckers TM, Scheiffele P, Bourgeron T, Brose N, Burbach JPH (2014) Neurobiology of autism gene products: towards pathogenesis and drug targets. Psychopharmacology. doi: 10.1007/s00213-013-3403-3

Murphy D, Spooren W (2012) EU-AIMS: a boost to autism research. Nat Rev Drug Discov 11:815-816

Murray ML, Hsia Y, Glaser K, Simonoff E, Murphy DGM, Asherson PJ, Eklund H, Wong ICK (2013) Pharmacological treatments prescribed to people with autism spectrum disorder (ASD) in primary health care. Psychopharmacology. doi: 10.1007/s00213-013-3140-7

Petrinovic MM, Künnecke B (2013) Neuroimaging endophenotypes in animal models of autism spectrum disorders: lost or found in translation? Psychopharmacology. doi: 10.1007/s00213-013$3200-\mathrm{z}$

Politte LC, McDougle CJ (2013) Atypical antipsychotics in the treatment of children and adolescents with pervasive developmental disorders. Psychopharmacology. doi: 10.1007/s00213013-3068-y

Pop AS, Levenga J, de Esch CEF, Buijsen RAM, Nieuwenhuizen IM, Li T, Isaacs A, Gasparini F, Oostra BA, Willemsen R (2012) Rescue of dendritic spine phenotype in Fmr1 KO mice with the mGluR5 antagonist AFQ056/Mavoglurant. Psychopharmacology. doi: 10. 1007/s00213-012-2947-y

Pop AS, Gomez-Mancilla B, Neri G, Willemsen R, Gasparini F (2013) Fragile X syndrome: a preclinical review on metabotropic glutamate receptor 5 (mGluR5) antagonists and drug development. Psychopharmacology. doi: 10.1007/s00213-013-3330-3

Ruggeri B, Sarkans U, Schumann G, Persico AM (2013) Biomarkers in autism spectrum disorder: the old and the new. Psychopharmacology. doi: 10.1007/s00213-013-3290-7

Vorstman JAS, Spooren W, Persico AM, Collier DA, Aigner S, Jagasia R, Glennon JC, Buitelaar JK (2013) Using genetic findings in autism for the development of new pharmaceutical compounds. Psychopharmacology. doi: 10.1007/s00213-013-3334-z 